\title{
Relationships among market orientation, learning orientation, organizational innovation and organizational performance: An empirical study in the Pearl River Delta region of China
}

\author{
(C) Higher Education Press and Springer-Verlag 2007
}

Abstract The purpose of this paper is to examine the relationships among market orientation, learning orientation, organizational innovation and organizational performance through a structural equation modeling approach. This study uses a sample of 143 companies in the Pearl River Delta region of China. Results show that (1) market orientation has no positive direct impact on organizational performance; (2) market orientation has a direct impact on learning orientation; (3) learning orientation has a direct impact on administrative and technical innovation; (4) market orientation has a direct impact on organizational innovation by learning orientation; (5) administrative innovation has a positive direct impact on organizational performance while technical innovation does not impact on organizational performance directly; (6) technical innovation has a positive impact on administrative innovation; (7) learning orientation has an indirect impact on organizational performance through influencing organizational innovation; (8) market orientation has impact on learning orientation, which has

\section{Translated from Guanli Shijie 管理世界 (Management World), 2006, (2): 80-94, 143}

XIE Hongming $(\bowtie)$, CHEN Chunhui

School of Business Administration, South China University of Technology, Guangzhou 510640, China

Institute of Strategic Management, Macao University of Science and Technology, Macao, China

E-mail: hmxie@scut.edu.cn

LIU Changyong

Department of Business Management, National Sun Yat-Sen University, Kaohsiung 804, Taiwan, China 
an impact on organizational innovation, which in turn has an impact on organizational performance. Managerial implications are discussed, along with suggestions for further research.

Keywords market orientation, learning orientation, administrative innovation, technical innovation, organizational performance

\section{Introduction}

In recent years, there has been a profound transformation in the management environment in China. The nation has gradually evolved from a planned economy to a market economy, while enterprises have changed from production workshops to independently operating economic entities, seeking opportunities to survive and develop in the market rather than simply to finish the production tasks given by the superior. The focus of enterprises has also changed from production in the past to making operational plan according to customers' demand. Marketing plays an increasingly important role in enterprises' operation. Many enterprises hope to improve their performance by strengthening market orientation and learning orientation.

Many empirical studies on whether or not and how market orientation influences organizational performance have been published, but final conclusion has not been reached yet. Langerak (2003) points out that it would still be a questionable proposition on whether and when market orientation has a positive impact on organizational performance after reviewing 51 relevant studies published in the international journals. In recent years, more and more scholars conducted empirical research on this issue, and it is still necessary to do further study. During the period of economic restructuring, can market-oriented enterprises achieve better organizational performance? Empirical results based on Chinese data of the issue have not been published yet, though Chinese scholars have begun to concern the issue and many of them believe that market-orientation is a key factor in obtaining competitive advantages. Enterprises which advocate market-oriented business ideas are blindness to some degrees because they do not have a strict scientific data basis to confirm the conclusion that market orientation has a positive impact on organizational performance in China.

In a developing country such as in China, many industries are still in their infancy. Under the background of economic internationalization, market globalization and technological advance, can market orientation, learning orientation and organizational innovation affect organizational performance in Chinese enterprises? And how does this impact take place? Do the related findings in developed countries match with that in China? These questions are not only academic issues, but also the problems need immediate solutions in the practice 
of enterprises. This paper aims to do an empirical study on these issues. The sample of this study involves 143 companies in the Pearl River Delta region of China. Our study can make important contributions to the literature on market orientation and organizational management, fill research gaps and provide guidance in relevant theory and practice for Chinese enterprises.

\section{Theoretical backgrounds and hypotheses}

\subsection{Market orientation and organizational performance}

Drucker (1954) argued that "there is only valid definition of business purpose: to create a customer...It is the customer who determines what the business is ... because its purpose is to create a customer; any business enterprise has only two basic functions: marketing and innovation”. In marketing, early researches focused on the discussion and development of marketing concept, while recently mainly focused on the measurement of market orientation and the relations between market orientation and other variables, such as performance. Many scholars considered that the marketing concept is the foundation of market orientation while market orientation is the implementation of the marketing concept. Market orientation is a certain kind of organizational culture which stresses customers, competitors and inter-functional coordination to create better customer value and build the competitive advantage (Narver et al., 1990). And most scholars regarded market orientation as one of the cores of modern marketing and strategic management.

For many years, there are various views on the concept of market orientation. Most scholars considered that the implementation of marketing concept is "marketing orientation" while some scholars considered that the implementation of marketing concept is "market orientation", and there are also some literatures using "customer orientation" as "marketing orientation". Shapiro (1988) argued that "marketing orientation" is so narrow as to be easily misleading that marketing orientation only is the duty for marketing department dealing with marketing activities. In fact, market orientation is not only the responsibility of marketing departments, but also the responsibility of all departments. Kohli and Jaworski (1990) suggests that only the term of "market orientation" can express the true meaning of marketing rather than "marketing orientation", mainly because (1) the marketing concept includes not only the function of marketing department but also others, and it seems to be so restrictive as to be mistaken for simply using "marketing orientation"; (2) market orientation can avoid the inflation of the importance of marketing department, and promote marketing department to coordinate and share responsibilities with other departments; (3) market orientation means focusing on the market, including customers and other factors affecting customers. In a word, Narver and Slater (1990) and other scholars define 
market orientation mainly from the view of philosophy or strategy emphasizing customer orientation, competitor orientation and inter-functional coordination; while Kohli and Jaworski (1990) define market orientation mainly according to the view of behaviors. Actually, market orientation has many characteristics, such as process, corporate culture and capabilities, and it is the effective measures for an organization to deal with various changes of external environment (Lin, 2001).

Although the issue of whether and how market orientation improves performance has been discussed for more than 30 years by scholars in the field of marketing, there are different conclusions in empirical studies. Many literatures found that performance were excellent in market-oriented organizations (Langerak, 2003). For example, Narver and Slater (1990) find that there was a positive relationship between market orientation and performance by analyzing the performance of non-commodity businesses. They measured market orientation by customer orientation, competitor orientation and coordination between departments. Moreover, organizations with high market orientation have the best performance while those with low market orientation also have good performance in commodity businesses. From the view of strategy, organizations with high market orientation are inclined to adopt diversification strategy while organizations with low market orientation are inclined to adopt low cost strategy. Diversification strategy and cost strategy are the two basic strategic choices for enterprises. But the performance of the organization with average market orientation is worse than the ones with high and low market orientation because it has not built strategy or lies in the situation of "nip in the middle" called by Porter (1980). Many Chinese enterprises are promoting the concept of market orientation and some enterprises have realized that market orientation have the great help on performance improvement. Thus, we hypothesize

$H 1$ : market orientation has a positive impact on organizational performance.

Although most scholars agree that market orientation can improve organizational performance, there are different results in a few studies. Therefore, some scholars doubt whether other mediating variables impact the relationship of market orientation and organizational performance, such as learning orientation (Baker and Sinkula, 1999), learning orientation (Slater and Narver, 1995; Lin, 2001), and organizational innovation (Han et al., 1998; Lin, 2001).

\subsection{Market orientation and learning orientation}

Facing the dynamic competitive environment, many corporations realize that they need continuous adjustment and innovation to suit the changes of environment, so learning orientation capabilities become one of the most important core competences (Chen and Ma, 2000). Learning orientation is also necessary for survival. March and Simon (1958) first began to study learning; Agryris and Schon (1978) first brought forward the concept of "learning 
orientation". They argue that learning orientation is a process through which the organization discovers errors and corrects these errors.

In addition, the concept of learning organization is much similar to the concept of learning orientation, but they are different. Senge (1990) suggests that learning organization develop people's capabilities to achieve the goals they desire. Learning organization assembles people to study consistently, and it describes the operation and patterns of organization focusing on the organizational system. Thus Senge (1990) considers that learning organization should encourage not only team learning but also systems perception. Learning orientation is inclined to describe the process and patterns of learning itself, focusing on learning orientation. Lin (2001) considers that learning orientation is a mechanism by which the culture of learning can promotes innovation.

According to the definition by Kohli and Jaworski (1990), market-oriented organizations should understand the needs of customers, collect relevant market information, and transfer the information between marketing department and cross-functional department, and then organizations carry out diversification strategy based on the needs of customers through combining all resources of organization. While a series of latest studies indicate that learning orientation has an impact on performance through improving the quality of market orientation behaviors and a direct impact on performance through learning promoting innovation of products, processes and systems. Slater and Narver (1995) also consider that market orientation and learning orientation interact; both of them can effectively improve organizational performance. They also consider that learning orientation is a link between market orientation and organizational performance. While Baker and Sinkula (1999) find that learning orientation (which is the higher level of learning orientation) and market orientation have a distinct positive impact on performance, besides, learning orientation and market orientation also have an integrated impact on performance according to the survey on top managers of marketing and non-marketing departments of 411 American companies. It means that the market orientation behavior of organization can hardly improve performance faster than its competitors if the organization does not have strong learning orientation. In addition, Lin (2001) has an empirical study about the relationship chain of market orientation-learning orientation-organizational performance through surveying high-tech enterprises in Taiwan. The result validated that learning orientation is a mediator between market orientation and organizational performance. Thus, we hypothesize

$H 2$ : market orientation has a positive impact on learning orientation.

\subsection{Market orientation and organizational innovation}

The concept of "innovation" began to attract attention in academe since Schumpeter (1934) brought forward two different concepts (innovation and 
invention) and emphasized innovation's importance in marketing economy. However, almost all the understanding of innovation in studies are different because of researchers' different interests and opinions (Wolfe, 1994), and up to now there is still great difference on the definition of "organizational innovation”. The basic viewpoint is that innovation may be a new product, service, technology or method of management. Previous scholars consider that innovation includes product innovation and process innovation. They overemphasized "technical innovation” while ignored “administrative innovation”. We define organizational innovation as "technical innovation" (product and process) and "administrative innovation” (system, policy, plan and service) according to multi-perspectives (Damanpour et al., 1991).

Scholars concern much on the issue whether enterprises with greater market orientation are inclined to develop newer product, and whether market orientation restrains technical innovation or not. Zaltman et al. (1973) argue that enterprises can achieve goals more effectively by proper collection of market information, decision and implementation of organizational innovation. They propose the relationship chain of market orientation-innovation-performance. Slater and Narver (1995) also regard innovation as a kind of "core value-creating capabilities". To some extent, most innovation and the success of new products come from market orientation. Quinn (1986) also suggests that enterprises with innovation have higher market orientation. Han et al. (1998) take the innovation, divided into technical innovation and administrative innovation, as the mediator to confirm the relationship of market orientation-innovation-performance taking the example of banking. As a result, they find that market-oriented behaviors can impact performance through the improvement of innovation and this relationship chain is not affected by environmental conditions (the turbulence of market and technique). Jaworski and Kohli (1993) propose that market orientation essentially relates to some different or new responses to the market and basically it can be taken as a kind of creative behavior. Slater (1997) also points out that the successful innovation is the result of combination of market-oriented culture and entrepreneur spirits. Based on the literatures above and interviews of enterprises, we hypothesize

H3a: market orientation has a positive impact on technical innovation;

$H 3 b$ : market orientation has a positive impact on management innovation.

\subsection{Learning orientation and organizational innovation}

Many studies indicate that learning orientation has an impact on organizational innovation. For example, Argyris and Schon (1978) consider that learning orientation can enhance the ability of innovation under the same organizational conditions. Stata (1989) finds that learning orientation leads to innovation; 
especially in the knowledge-intensive industries, the innovation, induced by personal and learning orientation, has become the source of continuous competitive advantage. Mabey and Salaman (1995) also regard learning orientation as the main factor for maintaining innovation. Glynn (1996) discusses the learning orientation ability can impact not only the beginning but also the implementation phases of innovation.

From the concept of learning experience curve, Foster (1986) deduces the $S$ learning curve of product innovation; moving along the curve means that some product innovation based on certain technical is being carried out and during the process, the increase of performance will gradually decline, while it must move to another technical curve for better performance. It means that better performance can be achieved with discontinuous innovation. Meanwhile, McKee (1992) indicates that different types of learning orientation lead to different types of innovation based on Foster (1986)'s model. For example, single loop learning only leads to incremental innovation while discontinuous innovation needs double loop learning. Thus learning orientation has positive effect on organizational innovation. This research gives hypothesis below based on the discussions of the relation of learning orientation and organizational innovation by scholars above

$H 4 a$ : learning orientation has a positive impact on technical innovation;

$H 4 b$ : learning orientation has a positive impact on administrative innovation.

\subsection{Organizational innovation and organizational performance}

Innovation becomes more and more important for organizational survival and development facing the cruel competition and uncertain competitive environment. Many researches confirm that organizational innovation has a positive impact on performance, and consider that innovation can lead to better organizational performance in whatever industries. This conclusion has been confirmed in many kinds of industries, such as public utilities (Damanpour and Evan, 1984), industry products and consumable manufacturing (Zahra et al., 1988), service (Subramanian and Nilakanta, 1996) and high-tech enterprises in Taiwan (Lin, 2001). According to the finding of Demanpour (1991) on the new theory of organizational innovation, most scholars approve and adopt the viewpoint of double cores model. This view proposes that innovation includes administrative innovation and technical innovation. Moreover, the impact of these two types of innovation on organizational performance has been examined by many scholars (Damanpour and Evan, 1984). The two types of innovation affect each other and have a combined impact on performance. Damanpour et al. (1989) find that a bank often needs a set of new administrative mechanism (administrative innovation) to evaluate and control its performance when it provides a new 
service (technical innovation) based on the survey of banking. However, every technical innovation can not lead to administrative innovation. Trist (1981) also suggests that if administrative innovation and technical innovation are adopted at the same time and equally, it would help to maintain the balance between internalfirm technical system and social structure. This paper gives hypothesis below based on the study of the impact relation of market orientation and organizational innovation to organizational performance by scholars above

H5a: administrative innovation has a positive impact on organizational performance;

$H 5 b$ : technical innovation has a positive impact on organizational performance;

H6: technical innovation has a positive impact on administrative innovation.

\section{Methods}

\subsection{Sample and data collection}

Prior to the collection of data, approximately a dozen business managers from Pearl River Delta region of China were personally interviewed to help determine whether differences in perceptions about this paper's variables could be discerned and whether items of the questionnaire could be understood easily. The individuals selected represented a diversity of industries and a range of managerial hierarchy (from top-level management to CEO). Based on numerous opened discussions, we concluded that it would be appropriate to sample subjects in upper to high organizational levels across different industries.

Data collection consisted of a random sample from Pearl River Delta region of China. About a total of 600 enterprises were drawn from the sampling frame which consisted of enterprises from Guangzhou, Shenzhen, Foshan, Zhongshan, Zhuhai and Huizhou etc. Data were assembled by two ways (1) interviewing the informants directly and getting the data after contacting with top managers of enterprises through telephone and obtaining permission for investigation; (2) we asked the students majored in Executive Master of Business Administration (EMBA) and exclusive manager trainees in South China University of Technology, Sun Yat-Sen University and Jinan University to fill in the questionnaires after class. These students mainly come from Pearl River Delta region of China with a certain cultural background and they can understand the content of the questionnaire. A total response of 156 (26\%) was obtained, yielding a usable response of 151 (25.16\%) fully completed questionnaires. There are 143 valid samples when eight questionnaires were deducted from the sample for that long-term performance will be examined in this paper. In Table 1, it shows that 
the share of the enterprises in manufacturing industry is about $46.2 \%$; meanwhile the one in serving industry is about $50.3 \%$. The share of the sample that enterprises have more than 2000 peoples is about $28.7 \%$.

Table 1 Description of data

\begin{tabular}{|c|c|c|}
\hline & Amount & Percentage $(\%)$ \\
\hline \multicolumn{3}{|c|}{ Industries of the informant firms } \\
\hline manufacturing & 66 & 46.2 \\
\hline serving & 72 & 50.3 \\
\hline others & 5 & 3.5 \\
\hline \multicolumn{3}{|c|}{ Age of the informant firms (year) } \\
\hline $4-6$ & 21 & 14.7 \\
\hline $7-9$ & 15 & 10.5 \\
\hline $10-12$ & 28 & 19.6 \\
\hline $13-15$ & 13 & 9.1 \\
\hline $16-20$ & 10 & 7.0 \\
\hline $21-25$ & 7 & 4.9 \\
\hline More than 25 & 49 & 34.3 \\
\hline \multicolumn{3}{|c|}{ Number of employees in the informant firms } \\
\hline Smaller than 50 & 14 & 9.8 \\
\hline $51-100$ & 10 & 7.0 \\
\hline $101-200$ & 14 & 9.8 \\
\hline $201-300$ & 6 & 4.2 \\
\hline $301-500$ & 13 & 9.1 \\
\hline $501-1000$ & 24 & 16.8 \\
\hline $1001-2000$ & 21 & 14.7 \\
\hline More than 2001 & 41 & 28.7 \\
\hline \multicolumn{3}{|c|}{$\begin{array}{l}\text { Rate of } R \& D / \text { Turnover of the informant } \\
\text { firms in the last three years }\end{array}$} \\
\hline Lower than $2.9 \%$ & 73 & 51.0 \\
\hline $3.0 \%-5.9 \%$ & 31 & 21.7 \\
\hline $6.0 \%-8.9 \%$ & 17 & 11.9 \\
\hline $9.0 \%-11.9 \%$ & 11 & 7.7 \\
\hline $12.0 \%-14.9 \%$ & 4 & 2.8 \\
\hline $15.0 \%-17.9 \%$ & 1 & 0.7 \\
\hline $18.0 \%-20.9 \%$ & 2 & 1.4 \\
\hline Higher than $21 \%$ & 4 & 2.8 \\
\hline \multicolumn{3}{|c|}{ Turnover of the informant firms (RMB) } \\
\hline Under 10 million & 12 & 8.4 \\
\hline 10.01-50 million & 28 & 19.6 \\
\hline 50.01-100 million & 20 & 14.0 \\
\hline 200-500 million & 22 & 15.4 \\
\hline 600-1000 million & 10 & 7.0 \\
\hline 1.1-2 billion & 16 & 11.2 \\
\hline 2.1-5 billion & 7 & 4.9 \\
\hline 5.1-10 billion & 12 & 8.4 \\
\hline More than 10.1 billion & 16 & 11.2 \\
\hline
\end{tabular}




\subsection{Measures}

Market orientation was measured with a five-item index based on previous research (Kumar et al., 1998; Narver and Slater, 1990). And an organization's customer orientation, competitor orientation, inter-functional coordination, long-term horizon and profit emphasis are the first-order indicators of a higher, second-order construct, namely, market orientation.

Learning orientation was adapted from Sinkula et al. (1997), and Baker and Sinkula (1999). Learning orientation was operated as a second-order construct with three dimensions (commitment to learning, shared version and open-mindedness).

Organizational innovation was adapted from Lin (2001). The characteristic of the questionnaire is that it defined organizational innovation based on five administrative functions which are planning, organizing, human resource (HR), leading, control and service. And the measure of organizational innovation includes three factors called HR and administrative innovation, organizing and planning innovation and technical innovation. There are 22 items in the questionnaire.

Organizational performance can be understood from different points of view and influenced by various levels of analysis and strategy. The measure of organizational performance in this paper refers to the study of Lin (2001) and adopts the method of self-evaluation with multiple factors or variables rather than a single one suggested by Steers (1975). In addition, it categorizes 12 questions on measuring performance in terms of their nature: short-term performance and long-term performance.

\subsection{Reliability and validity of the data}

This study validated the reliability of variables used Cronbach's $\alpha$ coefficient shown in Tables $2-5$. The Cronbach's $\alpha$ of every factor and every variable are inside the acceptable range, ensuring this questionnaire with better reliability.

All the items of questionnaire used in this paper come from literatures which have been published, and many scholars have used these items to scale correlative variables, believing that there are enough reliabilities and availabilities for the items. This paper has consulted many experts in correlative field, and carried out experimentation among managers of enterprises. In the end this paper corrected some items of questionnaire according to the advice of experts and top managers. So, the questionnaire is of much validity. But thinking about different culture, this paper still takes confirmatory factor analysis to confirm the validity of every scale about variables. Table 6 shows that the results of the confirmatory factor analysis can be accepted; meanwhile all factors of variables get significant discriminant validity, shown in Tables 7-10. 
Table 2 Reliability analysis of the scale of market orientation

\begin{tabular}{lcccc}
\hline Items & $\begin{array}{c}\text { Item-total } \\
\text { correlation }\end{array}$ & $\begin{array}{c}\text { Alpha if } \\
\text { item } \\
\text { deleted }\end{array}$ & $\begin{array}{c}\text { Coefficient } \\
\text { alpha } \\
\text { (cronbach’s } \alpha \text { ) }\end{array}$ & $\begin{array}{c}\text { Split-half } \\
\text { alpha } \\
\text { (guttman) }\end{array}$ \\
\hline
\end{tabular}

\section{Customer orientation}

(1) Showing commitment to patients

(2) Creating services that offer value for patients

(3) Understanding patients' needs

(4) Having patient satisfaction a major objective

(5) Measuring patient satisfaction

(6) Providing follow-up services

\section{Competitor orientation}

(7) People in charge of various services discuss competitor information

(8) People in charge of various service units respond rapidly to competitors' actions

(9) Senior managers discuss competitors' strategies

(10) Senior managers target opportunities for competitive advantage

Inter-functional coordination

(11) Various service units work close together to meet patients' needs

(12) Various service units share business information with each other

(13) Business strategies are integrated between different service units

(14) All service units work together in offering value to the patient

(15) Different service units share resources with each other

\section{Long-term horizon}

(16) Adopting long-term horizon in matters of profits

(17) Satisfying all key constituencies in the long term

(18) Aiming for positive profit margin in the long term

(19) Discovering and implementing new value for patients

(20) Trying to overcome any deficiency in services

$\begin{array}{ll}0.59 & 0.81 \\ 0.66 & 0.80 \\ & \\ 0.61 & 0.80 \\ 0.49 & 0.83 \\ & \\ 0.68 & 0.79 \\ 0.61 & 0.81\end{array}$

0.83

0.85

$0.47 \quad 0.74$

0.76

0.72

$0.62 \quad 0.66$

$0.58 \quad 0.68$

$0.53 \quad 0.712$

$0.61 \quad 0.83$

$0.66 \quad 0.82$

$0.68 \quad 0.82$

$0.65 \quad 0.83$

$0.72 \quad 0.80$

0.85

0.86

$$
0.83
$$

$0.61 \quad 0.80$

$0.52 \quad 0.83$

$0.71 \quad 0.78$

$0.64 \quad 0.80$ 
(Continued)

\begin{tabular}{lcccc}
\hline Items & $\begin{array}{c}\text { Item-total } \\
\text { correlation }\end{array}$ & $\begin{array}{c}\text { Alpha if } \\
\text { item } \\
\text { deleted }\end{array}$ & $\begin{array}{c}\text { Coefficient } \\
\text { alpha } \\
\text { (cronbach’s } \alpha \text { ) }\end{array}$ & $\begin{array}{c}\text { Split-half } \\
\text { alpha } \\
\text { (guttman) }\end{array}$ \\
\hline $\begin{array}{l}\text { Profit emphasis } \\
\text { (21) Requiring rapid payback of new } \\
\text { services/facilities }\end{array}$ & 0.42 & 0.79 & 0.79 & 0.75 \\
$\begin{array}{l}\text { (22) Profit performance is measured } \\
\text { for each service unit }\end{array}$ & 0.58 & 0.75 & & \\
$\begin{array}{l}\text { (23) Senior managers emphasize improved } \\
\text { performance relative to competitors }\end{array}$ & 0.53 & 0.76 & & \\
$\begin{array}{l}\text { (24) All service units are required to } \\
\text { be profitable }\end{array}$ & 0.65 & 0.72 & & \\
$\begin{array}{l}\text { (25) Emphasis on earning revenues } \\
\text { sufficient to cover expenses }\end{array}$ & 0.66 & 0.72 & & \\
$\begin{array}{l}\text { Market orientation (25 question items) } \\
\text { (25) }\end{array}$ & & & 0.93 & \\
\hline
\end{tabular}

\section{Results}

It is obvious that the reliability, constringency validity and discriminant validity of every variable in this sample all achieve the acceptable level, and it is feasible for single measuring indices to replace multiple measuring indices. Thus, when we test market orientation, organizational innovation and organizational performance, we consider the score of measuring questions of every factor on the first level to be the value of this factor and the first level factors to be the multiple measuring indices on the second level variables. For example, when we consider market orientation to be a latent variable, its observation variables are competitor orientation, customer orientation, inter-functional coordination, long-term horizon and survival and profit emphasis, decreasing the number of measuring indices effectively. First of all we used duplicate regression to analyze the relationship of every factor among market orientation and organizational innovation, market orientation and organizational performance, organizational innovation and organizational performance. Then we used structure equation model (SEM) to analyze the overall relationships between each variable.

\subsection{The relationships among the main factors in variables}

4.1.1 The relationship among market orientation and organizational performance, learning orientation, technical innovation

This study takes five factors of market orientation, i.e. customer orientation, competitor orientation, inter-functional coordination, long-term opinion and 
Table 3 Reliability analysis of the scale of learning orientation

\begin{tabular}{|c|c|c|c|c|}
\hline Items & $\begin{array}{l}\text { Item-total } \\
\text { correlation }\end{array}$ & $\begin{array}{l}\text { Alpha if } \\
\text { item } \\
\text { Deleted }\end{array}$ & $\begin{array}{c}\text { Coefficient } \\
\text { alpha } \\
\text { (cronbach’s } \alpha \text { ) }\end{array}$ & $\begin{array}{l}\text { Split-half } \\
\text { alpha } \\
\text { (guttman) }\end{array}$ \\
\hline Commitment to learning & & & 0.88 & 0.85 \\
\hline $\begin{array}{l}\text { (1) Managers basically agree that our } \\
\text { business unit's ability to learn is } \\
\text { the key to our competitive } \\
\text { advantage }\end{array}$ & 0.67 & 0.87 & & \\
\hline $\begin{array}{l}\text { (2) The basic values of this business } \\
\text { unit include learning as key to } \\
\text { improvement }\end{array}$ & 0.74 & 0.86 & & \\
\hline $\begin{array}{l}\text { (3) The sense around here is that } \\
\text { employee learning is an } \\
\text { investment, not an expense }\end{array}$ & 0.75 & 0.85 & & \\
\hline $\begin{array}{l}\text { (4) Learning in my organization is seen } \\
\text { as a key commodity necessary to } \\
\text { guarantee organizational survival }\end{array}$ & 0.74 & 0.85 & & \\
\hline $\begin{array}{l}\text { (5) The collective wisdom in this } \\
\text { enterprise is that once we quit } \\
\text { learning, we endanger our future }\end{array}$ & 0.71 & 0.86 & & \\
\hline Shared vision & & & 0.88 & 0.85 \\
\hline $\begin{array}{l}\text { (6) There is a well-expressed concept } \\
\text { of who we are and where we are } \\
\text { going as a business unit }\end{array}$ & 0.72 & 0.86 & & \\
\hline $\begin{array}{l}\text { (7) There is a total agreement on our } \\
\text { business unit vision across all } \\
\text { levels, functions, and divisions }\end{array}$ & 0.71 & 0.86 & & \\
\hline $\begin{array}{l}\text { (8) All employees are committed to } \\
\text { the goals of this business unit }\end{array}$ & 0.70 & 0.86 & & \\
\hline $\begin{array}{l}\text { (9) Employees view themselves as } \\
\text { partners in charting the direction } \\
\text { of the business unit }\end{array}$ & 0.74 & 0.86 & & \\
\hline $\begin{array}{l}\text { (10) Top leadership believes in sharing } \\
\text { its vision for the business unit } \\
\text { with the lower levels }\end{array}$ & 0.74 & 0.85 & & \\
\hline Open-mindedness & & & 0.79 & 0.71 \\
\hline $\begin{array}{l}\text { (11) We are not afraid to reflect critically } \\
\text { on the shared assumptions we have } \\
\text { about the way we do business }\end{array}$ & ly 0.58 & 0.74 & & \\
\hline $\begin{array}{l}\text { (12) Our business unit places a high } \\
\text { value on open-mindedness }\end{array}$ & 0.67 & 0.69 & & \\
\hline $\begin{array}{l}\text { (13) Managers encourage employees } \\
\text { to "think outside of the box." }\end{array}$ & 0.54 & 0.76 & & \\
\hline $\begin{array}{l}\text { (14) Original ideas are highly valued } \\
\text { in this organization }\end{array}$ & 0.58 & 0.74 & & \\
\hline \multicolumn{3}{|l|}{ Learning orientation (14 question items) } & 0.93 & 0.87 \\
\hline
\end{tabular}


Table 4 Reliability analysis of the scale of organizational innovation

\begin{tabular}{|c|c|c|c|c|}
\hline Items & $\begin{array}{l}\text { Item-total } \\
\text { correlation }\end{array}$ & \multirow{2}{*}{$\begin{array}{l}\text { Alpha } \\
\text { if item } \\
\text { Deleted }\end{array}$} & $\begin{array}{c}\text { Coefficient } \\
\text { alpha } \\
\text { (cronbach's } \alpha \text { ) }\end{array}$ & $\begin{array}{l}\text { Split-half } \\
\text { alpha } \\
\text { (guttman) }\end{array}$ \\
\hline HR and administration innovation & & & 0.92 & 0.90 \\
\hline $\begin{array}{l}\text { (1) Special compensation and } \\
\text { effectively motivating staff }\end{array}$ & 0.74 & 0.91 & & \\
\hline $\begin{array}{l}\text { (2) Managers would like to use new leading } \\
\text { methods and succeed in organizing } \\
\text { all staff to achieve the task. }\end{array}$ & 0.67 & 0.92 & & \\
\hline $\begin{array}{l}\text { (3) Setting up new system to assess } \\
\text { performance, this makes managers } \\
\text { know about the extent of the } \\
\text { staff's work. }\end{array}$ & 0.68 & 0.92 & & \\
\hline $\begin{array}{l}\text { (4) Special benefit for employees and } \\
\text { effectively motivating them }\end{array}$ & 0.71 & 0.91 & & \\
\hline $\begin{array}{l}\text { (5) Take new methods to lead the } \\
\text { staff and motivate them }\end{array}$ & 0.71 & 0.91 & & \\
\hline $\begin{array}{l}\text { (6) Applying new financial control system, } \\
\text { effectively checking the distance between } \\
\text { real performance and the plan }\end{array}$ & 0.60 & 0.92 & & \\
\hline $\begin{array}{l}\text { (7) The project to deal with the complaint } \\
\text { from customers now work well }\end{array}$ & 0.61 & 0.92 & & \\
\hline $\begin{array}{l}\text { (8) Special and different project to } \\
\text { hire workers and well done }\end{array}$ & 0.76 & 0.91 & & \\
\hline $\begin{array}{l}\text { (9) Taking new production system to } \\
\text { check the gap between real } \\
\text { performance and firm plan }\end{array}$ & 0.77 & 0.91 & & \\
\hline $\begin{array}{l}\text { (10) Special project to assess performance } \\
\text { and assessing employees' real } \\
\text { contribution to firm }\end{array}$ & 0.81 & 0.90 & & \\
\hline Organizational and planning innovation & & & 0.81 & 0.79 \\
\hline (11) New policies to improve performance & 0.57 & 0.78 & & \\
\hline $\begin{array}{l}\text { (12) Adjusting different departments' } \\
\text { authority and responsibility }\end{array}$ & 0.55 & 0.79 & & \\
\hline $\begin{array}{l}\text { (13) Changing the items of service and } \\
\text { improving the methods of service } \\
\text { by the demand of customer }\end{array}$ & 0.62 & 0.77 & & \\
\hline $\begin{array}{l}\text { (14) Trying different process to speed the } \\
\text { procedure of plan achievement }\end{array}$ & 0.62 & 0.77 & & \\
\hline $\begin{array}{l}\text { (15) Adjusting the colleague's work } \\
\text { just in time }\end{array}$ & 0.64 & 0.76 & & \\
\hline Administrative innovation & & & 0.93 & 0.91 \\
\hline Technical innovation & & & 0.87 & 0.83 \\
\hline $\begin{array}{l}\text { (16) New facility and equipment can } \\
\text { improve production and work } \\
\text { efficiency }\end{array}$ & 0.55 & 0.86 & & \\
\hline
\end{tabular}


(Continued)

Items

$\begin{array}{cccc}\begin{array}{c}\text { Item-total } \\ \text { correlation }\end{array} & \begin{array}{c}\text { Alpha } \\ \text { if item } \\ \text { Deleted }\end{array} & \begin{array}{c}\text { Coefficient } \\ \text { alpha } \\ \text { (cronbach’s } \alpha \text { ) }\end{array} & \begin{array}{c}\text { Split-half } \\ \text { alpha } \\ \text { (guttman) }\end{array}\end{array}$

(17) Colleagues often bring forward many $\quad 0.60 \quad 0.86$

different methods to improve

producing art and work process

(18) So much profit from new developed $\quad 0.63 \quad 0.86$

product and service

(19) Taking in new technology to improve $\quad 0.71 \quad 0.84$

producing art or work process

(20) Developing new products and service $\quad 0.71 \quad 0.84$

which are accepted by market

(21) Taking new product parts or services $\quad 0.70 \quad 0.85$

items to improve firm's operating

performance

(22) More number of patents than the $\quad 0.64 \quad 0.86$

other firms of the industry

Organizational Innovation (22 question items)

0.95

0.89

Table 5 Reliability analysis of the scale of organizational performance

\begin{tabular}{lcccc}
\hline Items & $\begin{array}{c}\text { Item-total } \\
\text { correlation }\end{array}$ & $\begin{array}{c}\text { Alpha } \\
\text { if item } \\
\text { deleted }\end{array}$ & $\begin{array}{c}\text { Coefficient } \\
\text { Alpha } \\
\text { (cronbach's } \alpha \text { ) }\end{array}$ & $\begin{array}{c}\text { Split-half } \\
\text { alpha } \\
\text { (guttman) }\end{array}$ \\
\hline Short-term performance & & & 0.87 & 0.84 \\
(1) Rate of sales growth & 0.74 & 0.83 & & \\
(2) Market share & 0.60 & 0.86 & & \\
(3) Rate of net profit & 0.72 & 0.83 & & \\
(4) Rate of sales profit & 0.75 & 0.83 & & \\
(5) Cash flow & 0.59 & 0.86 & & \\
(6) Investment rate of return & 0.61 & 0.85 & & \\
Long-term performance & & & & \\
(7) Performance of new product & 0.635 & 0.82 & & \\
$\quad$ development & & & & \\
(8) Performance of market development & 0.66 & 0.82 & & \\
(9) Innovation capability during the & 0.69 & 0.81 & & \\
$\quad$ process of product designing & & & & \\
$\quad$ and manufacturing & & 0.83 & \\
(10) Operating costs & 0.60 & 0.83 & & \\
(11) Prospects c of employee's & 0.69 & 0.81 & & \\
$\quad$ career development & & & & \\
(12) Public and social image & 0.53 & 0.84 & & \\
Organizational performance & & & & \\
$\quad$ (12 question items) & &
\end{tabular}


Table 6 Results of variables' confirmatory factor analysis

\begin{tabular}{lcccc}
\hline orientation & $\begin{array}{c}\text { Market } \\
\text { orientation }\end{array}$ & $\begin{array}{c}\text { Learning } \\
\text { innovation }\end{array}$ & $\begin{array}{c}\text { Organizational } \\
\text { performance }\end{array}$ & Organizational \\
\hline$G F I$ & 0.78 & 0.87 & 0.80 & 0.90 \\
CFI & 0.88 & 0.92 & 0.89 & 0.95 \\
$R M R$ & 0.069 & 0.046 & 0.051 & 0.047 \\
RMSEA & 0.079 & 0.096 & 0.084 & 0.082 \\
$\chi^{2}$ & $\chi^{2}(272)=512.69$ & $\chi^{2}(74)=166.33$ & $\chi^{2}(206)=411.44$ & $\chi^{2}(48)=93.51$ \\
\hline
\end{tabular}

Table 7 Discriminant validity analysis for market orientation

\begin{tabular}{|c|c|c|c|}
\hline Models & $\chi^{2}$ & d.f. & $\Delta \chi^{2}$ \\
\hline 1.Unlimited scale mode & 502.34 & 265 & \\
\hline $\begin{array}{l}\text { Attributing number ' } 1 \text { ' to the relationship between customer } \\
\text { orientation and competitor orientation }\end{array}$ & 532.40 & 266 & $30.06^{* * *}$ \\
\hline $\begin{array}{l}\text { Attributing number ' } 1 \text { ' to the relationship between customer } \\
\text { orientation and inter-functional coordination }\end{array}$ & 538.14 & 266 & $35.80^{* * *}$ \\
\hline $\begin{array}{l}\text { Attributing number ' } 1 \text { ' to the relationship between customer } \\
\text { orientation and long-term horizon }\end{array}$ & 538.93 & 266 & $36.59^{* * *}$ \\
\hline $\begin{array}{l}\text { Attributing number ' } 1 \text { ' to the relationship between customer } \\
\text { orientation and profit emphasizing }\end{array}$ & 540.49 & 266 & $38.15^{* * *}$ \\
\hline $\begin{array}{l}\text { Attributing number ' } 1 \text { ' to the relationship between competitor } \\
\text { orientation and inter-functional coordination }\end{array}$ & 542.66 & 266 & $40.32^{* * *}$ \\
\hline $\begin{array}{l}\text { Attributing number ' } 1 \text { ' to the relationship between competitor } \\
\text { orientation and long-term horizon }\end{array}$ & 544.56 & 266 & $42.22^{* * *}$ \\
\hline $\begin{array}{l}\text { Attributing number ' } 1 \text { ' to the relationship between competitor } \\
\text { orientation and profit emphasizing }\end{array}$ & 534.14 & 266 & $31.80^{* * *}$ \\
\hline $\begin{array}{l}\text { Attributing number ' } 1 \text { ' to the relationship between inter-functional } \\
\text { coordination and long-term horizon }\end{array}$ & 546.83 & 266 & $44.49^{* * *}$ \\
\hline $\begin{array}{l}\text { Attributing number ' } 1 \text { ' to the relationship between inter-functional } \\
\text { coordination and profit emphasizing }\end{array}$ & 553.07 & 266 & $50.73^{* * *}$ \\
\hline $\begin{array}{l}\text { Attributing number ' } 1 \text { ' to the relationship between long-term } \\
\text { horizon and profit emphasizing }\end{array}$ & 554.27 & 266 & $51.93^{* * *}$ \\
\hline
\end{tabular}

Note: $\Delta \chi^{2}$ is counted by the unlimited mode; ${ }^{* * *} p<0.001$.

Table 8 Discriminant validity analysis for learning orientation

\begin{tabular}{lrrr}
\hline Models & $\chi^{2}$ & d.f. & $\Delta \chi^{2}$ \\
\hline $\begin{array}{l}\text { 1.Unlimited scale mode } \\
\text { Attributing number ' } 1 \text { ' to the relationship between }\end{array}$ & 166.33 & 74 & \\
$\quad$ commitment to learning and shared vision & 191.45 & 75 & $25.12^{* * *}$ \\
$\begin{array}{l}\text { Attributing number ' } 1 \text { ' to the relationship between } \\
\quad \text { commitment to learning and open-mindedness }\end{array}$ & 200.72 & 75 & $34.39^{* * *}$ \\
$\begin{array}{l}\text { Attributing number ' } 1 \text { ' to the relationship between } \\
\quad \text { shared vision and open-mindedness }\end{array}$ & 193.32 & 75 & $26.99^{* * *}$ \\
\hline
\end{tabular}

Note: $\Delta \chi^{2}$ is counted by the unlimited mode; ${ }^{* * *} p<0.001$. 
Table 9 Discriminant validity analysis for administrative innovation

\begin{tabular}{lccc}
\hline Models & $\chi^{2}$ & d.f. & $\Delta \chi^{2}$ \\
\hline 1.Unlimited scale mode & 221.90 & 89 & \\
Attributing number '1' to the relationship between & 259.95 & 90 & $38.05^{* * *}$ \\
$\quad$ HR and administrative innovation and & & & \\
$\quad$ organizing and planning innovation & & & \\
\hline
\end{tabular}

Note: $\Delta \chi^{2}$ is counted by the unlimited mode; ${ }^{* * *} p<0.001$.

Table 10 Discriminant validity analysis for organizational performance

\begin{tabular}{lccc}
\hline Models & $\chi^{2}$ & d.f. & $\Delta \chi^{2}$ \\
\hline 1.Unlimited scale mode & 154.32 & 53 & \\
Attributing number '1' to the relationship & 190.13 & 54 & $35.81^{* * *}$ \\
$\quad$ between short-term performance and & & & \\
$\quad$ long-term performance & & & \\
\hline
\end{tabular}

Note: $\Delta \chi^{2}$ is counted by the unlimited mode; ${ }^{* * *} p<0.001$.

survival and profit emphasis, as independent variables, and also takes three factors of learning orientation, namely, commitment to learning, shared vision and open-mindedness, together with four factors of organizational innovation, namely, HR and administrative innovation, organizing and planning innovation, administrative innovation, technical innovation, as dependent variables to do duplicate regression analysis. The result is shown in Table 11. It is obvious that competitor orientation and inter-functional coordination have a significant positive impact on both short-term and long-term performances. We can also found that inter-functional coordination has dramatically significant impacts on factors of organizational performance. This shows again it is very important to enhance the ability of inter-functional coordination for enterprises in China to improve organizational performance. Other factors of market orientation, such as customer orientation, inter-functional coordination, long-term opinion and survival and profit emphasis, have no significant impact on short-term performance or long-term performance and even customer orientation has a certain negative impact on organizational performance.

We found that the three factors of market orientation which are inter-functional coordination, long-term opinion and survival and profit emphasis have distinct positive impact on commitment to learning; competitor orientation, inter-functional coordination and long-term opinion have significant positive impacts on shared vision of learning orientation; and competitor orientation and long-term opinion have significant positive impacts on open-mindedness.

We also find that all factors of organizational innovation have no significant impact on HR and administrative innovation; the three factors of market 
Table 11 Impact of market orientation on other factors

\begin{tabular}{|c|c|c|c|c|c|c|c|c|c|}
\hline \multirow[t]{2}{*}{ Independent } & \multicolumn{9}{|c|}{ Dependent } \\
\hline & $\begin{array}{l}\text { short- } \\
\text { term } \\
\text { perfor- } \\
\text { mance }\end{array}$ & $\begin{array}{l}\text { long- } \\
\text { term } \\
\text { perfor- } \\
\text { mance }\end{array}$ & $\begin{array}{l}\text { commit- } \\
\text { ment } \\
\text { to } \\
\text { learning }\end{array}$ & $\begin{array}{l}\text { shared } \\
\text { version }\end{array}$ & $\begin{array}{l}\text { open- } \\
\text { min- } \\
\text { dedness }\end{array}$ & $\begin{array}{l}\mathrm{HR} \text { and } \\
\text { adminis- } \\
\text { trative } \\
\text { innovation }\end{array}$ & $\begin{array}{c}\text { organizing } \\
\text { and } \\
\text { planning } \\
\text { innovation }\end{array}$ & $\begin{array}{l}\text { adminis- } \\
\text { trative } \\
\text { innovation }\end{array}$ & $\begin{array}{l}\text { technical } \\
\text { innovation }\end{array}$ \\
\hline $\begin{array}{l}\text { customer } \\
\text { orientation }\end{array}$ & $\begin{array}{c}0.04 \\
(0.732)\end{array}$ & $\begin{array}{c}-0.11 \\
(0.345)\end{array}$ & $\begin{array}{c}0.12 \\
(0.222)\end{array}$ & $\begin{array}{c}-0.12 \\
(0.159)\end{array}$ & $\begin{array}{c}0.02 \\
(0.876)\end{array}$ & $\begin{array}{c}-0.03 \\
(0.727)\end{array}$ & $\begin{array}{c}-0.16 \\
(0.098)\end{array}$ & $\begin{array}{l}-0.075 \\
(0.396)\end{array}$ & $\begin{array}{c}-0.02 \\
(0.833)\end{array}$ \\
\hline $\begin{array}{l}\text { competitor } \\
\text { orientation }\end{array}$ & $\begin{array}{c}0.25^{*} \\
(0.017)\end{array}$ & $\begin{array}{c}0.22^{*} \\
(0.027)\end{array}$ & $\begin{array}{c}0.13 \\
(0.149)\end{array}$ & $\begin{array}{c}0.32 * * * \\
(0.000)\end{array}$ & $\begin{array}{c}0.17^{*} \\
(0.044)\end{array}$ & $\begin{array}{c}0.16 \\
(0.059)\end{array}$ & $\begin{array}{c}0.17 * \\
(0.042)\end{array}$ & $\begin{array}{l}0.170^{*} \\
(0.028)\end{array}$ & $\begin{array}{c}0.15 \\
(0.084)\end{array}$ \\
\hline $\begin{array}{l}\text { inter-functional } \\
\text { coordination }\end{array}$ & $\begin{array}{c}0.25^{*} \\
(0.027)\end{array}$ & $\begin{array}{c}0.43^{* * *} \\
(0.000)\end{array}$ & $\begin{array}{c}0.20 * \\
(0.039)\end{array}$ & $\begin{array}{c}0.43^{* * *} \\
(0.000)\end{array}$ & $\begin{array}{c}0.21 \\
(0.876)\end{array}$ & $\begin{array}{c}-0.03 \\
(0.727)\end{array}$ & $\begin{array}{c}0.36 * * * \\
(0.000)\end{array}$ & $\begin{array}{c}0.491 * * * \\
(0.000)\end{array}$ & $\begin{array}{c}0.40 * * * \\
(0.000)\end{array}$ \\
\hline $\begin{array}{l}\text { long-term } \\
\text { horizon }\end{array}$ & $\begin{array}{c}0.15 \\
(0.198)\end{array}$ & $\begin{array}{c}0.09 \\
(0.413)\end{array}$ & $\begin{array}{l}0.26 * * \\
(0.009)\end{array}$ & $\begin{array}{c}0.21^{*} \\
(0.014)\end{array}$ & $\begin{array}{c}0.40 * * * \\
(0.000)\end{array}$ & $\begin{array}{c}0.16 \\
(0.074)\end{array}$ & $\begin{array}{c}0.38 * * * \\
(0.000)\end{array}$ & $\begin{array}{c}0.241^{* *} \\
(0.005)\end{array}$ & $\begin{array}{c}0.17 \\
(0.068)\end{array}$ \\
\hline $\begin{array}{l}\text { profit } \\
\text { emphasis }\end{array}$ & $\begin{array}{c}-0.06 \\
(0.453)\end{array}$ & $\begin{array}{c}0.07 \\
(0.394)\end{array}$ & $\begin{array}{c}0.16^{*} \\
(0.028)\end{array}$ & $\begin{array}{c}0.08 \\
(0.206)\end{array}$ & $\begin{array}{c}0.09 \\
(0.166)\end{array}$ & $\begin{array}{c}0.50 \\
(0.365)\end{array}$ & $\begin{array}{c}0.09 * \\
(0.172)\end{array}$ & $\begin{array}{c}0.074 \\
(0.234)\end{array}$ & $\begin{array}{l}0.20 * * \\
(0.005)\end{array}$ \\
\hline$F$ & $12.69 * * *$ & $16.43^{* * *}$ & $26.35 * * *$ & $43.67 * * *$ & $33.82 * * *$ & * 33.77 *** & $31.38^{* * *}$ & $42.72 * * *$ & $30.81^{* * *}$ \\
\hline$R^{2}$ & 0.32 & 0.38 & 0.49 & 0.61 & 0.55 & 0.55 & 0.53 & 0.61 & 0.53 \\
\hline Adjusted $R^{2}$ & 0.29 & 0.35 & 0.47 & 0.60 & 0.54 & 0.54 & 0.52 & 0.60 & 0.51 \\
\hline
\end{tabular}

Note: $* p<0.05 ; * * p<0.01 ; * * * p<0.001$.

orientation which are competitor orientation, inter-functional coordination and long-term opinion have distinct positive impact on organizing and planning innovation, namely, the higher degree of enterprises' competitor orientation and inter-functional and the more emphasis on long-term opinion, the higher degree of organizing and planning innovation; the two factors of market orientation which are inter-functional coordination, survival and profit emphasis have distinct positive impacts on technical innovation, that is the higher degree of inter-functional and survival and profit emphasis the higher degree of technical innovation; in a word, the three factors of market orientation which are competitor orientation, inter-functional coordination and long-term opinion have a significant positive impact on administrative innovation, namely, the higher degree of competitor orientation, inter-functional and the more attention paid to the long-term opinion the higher degree of technical innovation. We also find that customer orientation has no significant impact on all factors of organizational innovation even with a certain negative impact. This shows that the innovation behavior in enterprises in China does not really match with the needs of customer.

\subsubsection{The relationship between learning orientation and organizational innovation}

This study takes three factors of learning orientation as independent variables while four factors of innovation as dependent variables, and the result is shown in Table 12. We find that shared vision and open-mindedness have distinct positive 
Table 12 Impact of learning orientation on organizational innovation

\begin{tabular}{lcccc}
\hline Independent & \multicolumn{4}{c}{ Dependent } \\
\cline { 2 - 5 } & $\begin{array}{c}\text { HR and administrative } \\
\text { innovation }\end{array}$ & $\begin{array}{c}\text { Organizing and } \\
\text { planning } \\
\text { innovation }\end{array}$ & $\begin{array}{c}\text { Administrative } \\
\text { innovation }\end{array}$ & $\begin{array}{c}\text { Technical } \\
\text { innovation }\end{array}$ \\
\hline Commitment to & $0.11(0.143)$ & $0.26^{* * *}(0.000)$ & $0.17^{*}(0.022)$ & $0.04(0.639)$ \\
$\quad$ learning & $0.41^{* * *}(0.000)$ & $0.13(0.160)$ & $0.35^{* * *}(0.000)$ & $0.38^{* * *}(0.000)$ \\
Shared version & $0.36^{* * *}(0.000)$ & $0.26^{* * *}(0.000)$ & $0.40^{* * *}(0.000)$ & $0.37^{* * *}(0.000)$ \\
Open-mindedness & $83.59^{* * *}$ & $60.00^{* * *}$ & $103.46^{* * *}$ & $51.16^{* * *}$ \\
$F$ value & 0.64 & 0.56 & 0.69 & 0.53 \\
$R^{2}$ & 0.64 & 0.56 & 0.68 & 0.52 \\
Adjusted $R^{2}$ & & & &
\end{tabular}

Note: ${ }^{*} p<0.05 ;{ }^{* *} p<0.01 ;{ }^{* * *} p<0.001$.

impact on the factor of HR and administrative innovation, which is the higher degree of shared vision and open-mindedness the higher degree of HR and administrative innovation; commitment to learning and open-mindedness of learning orientation have significant positive impacts on organizing and planning innovation; the three factors of learning orientation have significant positive impacts on administrative innovation; shared vision and open-mindedness of learning orientation have significant positive impacts on technical innovation, namely, the higher degree of shared vision and open-mindedness the higher degree of organizational technical innovation.

\subsubsection{The relationship between organizational innovation and organizational performance}

We considered the three factors of organizational innovation as independent variables while the two factors of organizational performance (short-term performance and long-term performance) as dependent variables, then we duplicated regression analysis and the result is shown in Table 13. We find that both HR and administrative innovation and technical innovation have significant impact on organizational short-term performance and long-term performance. It means that the more advanced HR and administrative innovation and technical innovation are, the better short-term performance and long-term performance are. We also find that the impact on short-term performance by HR and administrative innovation and technical innovation is less than the impact on long-term performance. It shows that neither administrative innovation nor technical innovation has little impact on short-term performance, but profound impact on long-term performance. At the same time, organizational and programming innovations have neither significant positive impact nor negative impact on organizational performance. 
Table 13 Impact of organizational innovation on organizational performance

\begin{tabular}{lcccc}
\hline Independent & \multicolumn{4}{c}{ Dependent } \\
\cline { 2 - 5 } & $\begin{array}{c}\text { Short-term } \\
\text { performance }\end{array}$ & $\begin{array}{c}\text { Long-term } \\
\text { performance }\end{array}$ & $\begin{array}{c}\text { Short-term } \\
\text { performance }\end{array}$ & $\begin{array}{c}\text { Long-term } \\
\text { performance }\end{array}$ \\
\hline HR and administrative & $0.46^{* * *}(0.000)$ & $0.52^{* * *}(0.000)$ & \\
$\quad$ innovation & & & & \\
Organizing and planning & $-0.19(0.067)$ & $-0.09(0.319)$ & & \\
$\quad$ innovation & & & $0.28^{*}(0.011)$ & $0.43^{* * *}(0.000)$ \\
Administrative innovation & & & $0.32^{* *}(0.004)$ & $0.33^{* * *}(0.001)$ \\
Technical innovation & $0.30^{* * *}(0.000)$ & $0.32^{* * *}(0.001)$ & $0.31 .92^{* * *}$ & $71.79^{* * *}$ \\
$F$ & $25.06^{* * *}$ & $52.35^{* * *}$ & 0.31 & 0.51 \\
$R^{2}$ & 0.35 & 0.53 & 0.30 & 0.50 \\
Adjusted $R^{2}$ & 0.34 & 0.52 & &
\end{tabular}

Note: ${ }^{*} p<0.05 ;{ }^{* *} p<0.01 ;{ }^{* * *} p<0.001$.

We consider the two factors of organizational innovation (administrative innovation and technical innovation) to be independent variables and the two factors of organizational performance (short-term performance and long-term performance) to be consequent variables. Then we can carry through duplicate regression analysis. We find that the two factors of organizational innovation have significant positive impacts on the two factors of organizational performance. Organizational innovation can promote the development of organizational performance.

4.2 The relationships among market orientation, learning orientation, organizational innovation and organizational performance

We have analyzed the relationships among all the factors above, ignoring the impact of other variables and interaction among the overall variable. Then we make use of SEM to analyze the relationships among market orientation, learning orientation, organizational innovation and organizational performance, and to test the hypothesis. Structure equation model is made up of organic integration of path analysis and factor analysis. It utilizes some statistical methods to cope with the complicated theory model, and evaluate the theory model properly by the level of coherence between the model and data. Consequently, we can prove the theory model which we assumed above.

\subsubsection{The theory model}

Fig. 1 shows the theory model of this paper. The latent construct is represented by ellipse while observed variable is represented by rectangle. 


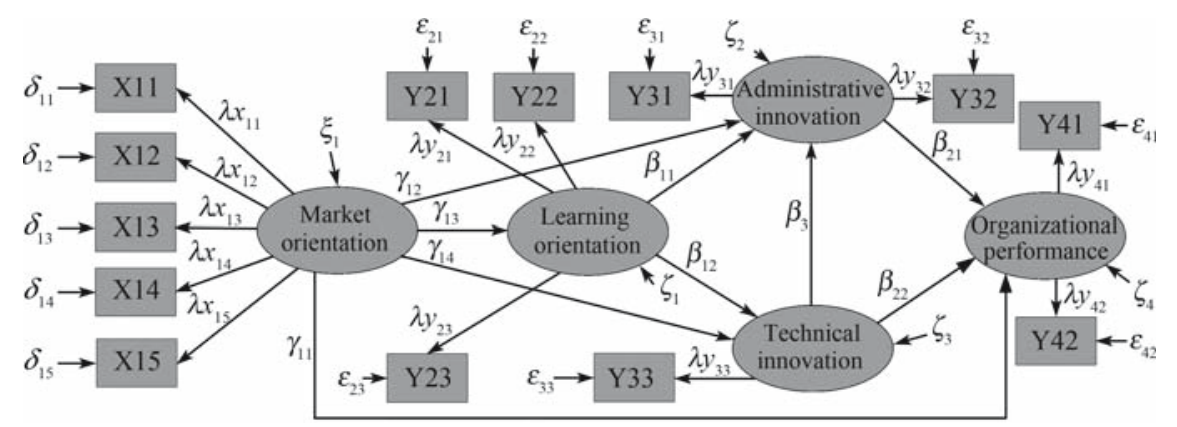

Fig. 1 Theory model and parameter structure

\subsubsection{The test of overall model}

Though different scholars use different methods to test the SEM, primary indices are the same. Bagozzi and Yi (1988) thought that we must use basic preliminary fit criteria, overall model fit and fit of internal structure of model to test the overall theory model.

(a) Preliminary fit criteria: this standard is used to test the error, identification and whether we made mistakes in inputting, what can be measured by the error of index cannot be negative; the factor charge cannot be lower than 0.5 or higher than 0.95 and whether it achieves distinct level. Table 14 shows that the factor charge of the measuring index of every potential factor in this paper all achieves distinct level. So, the theory model we proposed is coherent with the Preliminary fit criteria.

(b) Overall model fit: this index is used to test the fit of the overall model and the observed data, the measuring criteria of which have many indices. Hair et al. (1998) considered there are three types of it, i.e. absolute fit measures, incremental fit measures and parsimonious fit measures. Absolute fit measures: $\chi^{2}=111.46$, d.f. $=57, G F I=0.90, R M R=0.02, R M S E A=0.08$. It is obvious that $G F I$ and $R M R$ are both acceptable and only CFI and RMSEA is a little bigger. Incremental fit measures: $A G F I=0.83, N F I=0.92, C F I=0.96$. It is obvious that $N F I$ and $C F I$ are both acceptable while AGFI is lower than 0.9. Parsimonious fit measures: $P N F I=0.67, P C F I=0.70$. These indices are not perfect. As a whole the overall model fit of the theory model in this paper is acceptable according to the judge of every index.

(c) Fit of internal structure of model: this criterion is used to evaluate the distinct level of the estimate parameter and the reliability of every index and potential variables. This can be evaluated by whether or not individual item reliability is above 0.5 , composite reliability of potential variables is above 0.7 and variance extracted of potential variables is above 0.5 . Table 5 shows that the 
Table 14 Analysis of the whole theory model

\begin{tabular}{|c|c|c|c|c|}
\hline & \multicolumn{2}{|c|}{ Estimate parameters of MLE } & \multirow[t]{2}{*}{ Cronbach's $\alpha$} & \multirow[t]{2}{*}{ Extraction } \\
\hline & $\begin{array}{l}\text { Factor score } \\
\text { weights }(\lambda)\end{array}$ & $\begin{array}{l}\text { Error } \\
(\delta \text { or } \varepsilon)\end{array}$ & & \\
\hline Market orientation & & & 0.86 & 0.65 \\
\hline Customer orientation & $0.80^{* *}$ & 0.64 & & \\
\hline Competitor orientation & $0.76^{* *}$ & 0.58 & & \\
\hline Inter-functional coordination & $0.84^{* *}$ & 0.71 & & \\
\hline Long-term horizon & $0.83^{* * *}$ & 0.70 & & \\
\hline Profit emphasis & $0.49^{* * *}$ & 0.24 & & \\
\hline Learning orientation & & & 0.88 & 0.81 \\
\hline Commitment to learning & $0.80^{* * *}$ & 0.64 & & \\
\hline Shared vision & $0.89^{* * *}$ & 0.79 & & \\
\hline Open-mindedness & $0.84^{* * *}$ & 0.71 & & \\
\hline Administrative innovation & & & 0.84 & 0.87 \\
\hline HR and administrative innovation & $0.92^{* *}$ & 0.85 & & \\
\hline Organizing and planning innovation & $0.80^{*}$ & 0.64 & & \\
\hline Organizational performance & & & 0.81 & 0.84 \\
\hline Short-term performance & $0.75^{* * *}$ & 0.56 & & \\
\hline Long-term performance & $0.91^{* * *}$ & 0.83 & & \\
\hline
\end{tabular}

Note: $\chi^{2}=111.46$, d.f. $=57, G F I=0.89, R M R=0.021, R M S E A=0.085 ; A G F I=0.83$, $N F I=0.92, C F I($ comparatively fit index $)=0.96 ; P N F I=0.67, P G F I=0.70$.

composite reliability of market orientation, learning orientation, administrative innovation and organizational performance are $0.86,0.88,0.84$ and 0.81 while the variance extracted are $0.65,0.81,0.87,0.84$ and they all exceed the lowest acceptable level. So, the overall theory model indicated in this paper has a perfect internal structure fit. And it is obvious that the model is suitable, which can be used to test the relative hypothesis.

\subsection{Test of hypothesis}

We use Nested-model approach to test hypothesis and set 9 nested-models between the null model $\left(M_{0}\right)$ and theory model $\left(M_{\mathrm{t}}\right)$. $M_{1}$ mode is used to test the relationship between organizational performance and market orientation. $M_{2}$ mode is used to test the relationship between administrative innovation and market orientation. $M_{3}$ mode is used to test the relationship between learning orientation and market orientation. $M_{4}$ mode is used to test the relationship between technical innovation and market orientation. $M_{5}$ mode is used to test the relationship between administrative innovation and learning orientation. $M_{6}$ mode is used to test the relationship between technical innovation and learning orientation. $M_{7}$ mode is used to test the relationship between organizational performance and administrative innovation. $M_{8}$ mode is used to test the 
relationship between organizational performance and technical innovation. $M_{9}$ mode is used to test the relationship between administrative innovation and technical innovation. The theory model is established according to the view of the framework of this study while the null model refers to the mode whose route coefficients among potential variables are all limited to 0 and the fit of this mode is worst, which can be the basis of the calculation on CFI. The analysis results are shown in Table 15.

Table 15 Compare analysis of nested-model approach $(n=143)$

\begin{tabular}{lrcccccc}
\hline Model & $\chi^{2}$ & $d . f$. & $\Delta \chi^{2}$ & GFI & CFI & RMSEA & $R M R$ \\
\hline$M_{\mathrm{t}}:$ theory model & 111.46 & 57 & & 0.89 & 0.96 & 0.085 & 0.021 \\
$M_{1}: \gamma_{11}=0$ & 111.47 & 58 & 0.01 & 0.89 & 0.96 & 0.083 & 0.021 \\
$M_{2}: \gamma_{12}=0$ & 111.60 & 58 & 0.14 & 0.89 & 0.96 & 0.083 & 0.021 \\
$M_{3}: \gamma_{13}=0$ & 249.11 & 58 & $137.65^{* * *}$ & 0.83 & 0.85 & 0.157 & 0.156 \\
$M_{4}: \gamma_{14}=0$ & 113.71 & 58 & 2.25 & 0.89 & 0.96 & 0.085 & 0.022 \\
$M_{5}: \beta_{11}=0$ & 129.34 & 58 & $17.88^{* * *}$ & 0.88 & 0.95 & 0.096 & 0.022 \\
$M_{6}: \beta_{12}=0$ & 115.46 & 58 & $4.00^{*}$ & 0.89 & 0.96 & 0.086 & 0.021 \\
$M_{7}: \beta_{21}=0$ & 119.09 & 58 & $7.63^{* *}$ & 0.88 & 0.95 & 0.089 & 0.021 \\
$M_{8}: \beta_{22}=0$ & 114.65 & 58 & 3.19 & 0.89 & 0.96 & 0.086 & 0.022 \\
$M_{9}: \beta_{3}=0$ & 120.62 & 58 & $9.16^{* *}$ & 0.89 & 0.95 & 0.090 & 0.021 \\
$M_{0}:$ Null model & 1364.19 & 78 & 1252.73 & 0.20 & 0.00 & 0.352 & 0.267 \\
\hline
\end{tabular}

Note: The calculation of $\Delta \chi^{2}$ uses the theory model $\left(\chi^{2}=72.92\right.$, d.f. $\left.=30\right)$, and the calculation of CFI uses the null model $\left(\chi^{2}=1364.19\right.$, d.f. $\left.=57\right) ;{ }^{*} p<0.05\left(\chi^{2}(1)=3.84\right),{ }^{* *} p<0.01$ $\left(\chi^{2}(1)=6.63\right),{ }^{* * *} p<0.001\left(\chi^{2}(1)=10.83\right)$.

(a) The relationship between organizational performance and market orientation: this study supposed that market orientation has a positive impact on organizational performance (H1) and we found that the fit of $M_{1}$ mode has no significant difference $\left(\Delta \chi^{2}=0.01, \Delta d\right.$.f. $\left.=1\right)$, which shows that market orientation has no significant direct impact on organizational performance. While from the route coefficients of the theory model in Table 7, we can also found that the route coefficient of market orientation to organizational performance does not achieve distinct level and there is no direct impact effect $\left(\gamma_{21}=0.01\right)$, which shows that the higher degree of market orientation does not mean the higher degree of organizational performance. So, market orientation has no direct distinct positive impact on organizational performance. And $H 1$ is not supported.

(b) The relationship between learning orientation and market orientation: this study supposed that market orientation has a positive impact on learning orientation ( $\mathrm{H} 2)$ and we found that the fit of $M_{3}$ mode has distinct differences $\left(\Delta \chi^{2}=137.65, \Delta\right.$ d.f. $\left.=1, p<0.001\right)$, which shows that market orientation undoubtedly has a distinct direct impact on learning orientation. While from the route coefficients of the theory model in Table 7, we can also found that market 
Table 16 The route coefficient and hypothesis validation of the theory model

\begin{tabular}{|c|c|c|c|c|c|}
\hline Route & Relations among variables & $\begin{array}{c}\text { Route } \\
\text { coefficient }\end{array}$ & $P$ value & $\begin{array}{l}\text { Corresponding } \\
\text { hypothesis }\end{array}$ & Results \\
\hline$\gamma_{11}$ & $\begin{array}{l}\text { Market orientation } \rightarrow \\
\text { organizational performance }\end{array}$ & 0.01 & 0.949 & $H 1$ & Not support \\
\hline$\gamma_{12}$ & $\begin{array}{l}\text { Market orientation } \rightarrow \\
\text { administrative innovation }\end{array}$ & -0.07 & 0.704 & HЗ & Not support \\
\hline$\gamma_{13}$ & $\begin{array}{l}\text { Market orientation } \rightarrow \\
\text { Learning orientation }\end{array}$ & $0.91^{* * *}$ & 0.000 & $H 2$ & Support \\
\hline$\gamma_{14}$ & $\begin{array}{l}\text { Market orientation } \rightarrow \\
\text { technical innovation }\end{array}$ & 0.34 & 0.107 & $H 3 b$ & Not support \\
\hline$\beta_{11}$ & $\begin{array}{l}\text { Learning orientation } \rightarrow \\
\text { administrative innovation }\end{array}$ & $0.79^{*}$ & 0.032 & $H 4 a$ & Support \\
\hline$\beta_{12}$ & $\begin{array}{l}\text { Learning orientation } \rightarrow \\
\text { technical innovation }\end{array}$ & $0.45^{* * *}$ & 0.000 & $H 4 b$ & Support \\
\hline$\beta_{21}$ & $\begin{array}{l}\text { administrative innovation } \rightarrow \\
\text { organizational performance }\end{array}$ & $0.59^{* *}$ & 0.006 & $H 5 b$ & Support \\
\hline$\beta_{22}$ & $\begin{array}{l}\text { technical innovation } \rightarrow \\
\text { organizational performance }\end{array}$ & 0.23 & 0.071 & $H 5 a$ & Not support \\
\hline$\beta_{3}$ & $\begin{array}{l}\text { technical innovation } \rightarrow \\
\text { administrative innovation }\end{array}$ & $0.28^{* * *}$ & 0.001 & H6 & Support \\
\hline
\end{tabular}

Note: The route coefficient is standardization value.

orientation has positive route coefficient to learning orientation and it has a positive direct effect $\left(\gamma_{11}=0.91, p<0.001\right)$, which shows that the higher degree of market orientation matches with the higher degree of producing learning orientation. So, market orientation undoubtedly has a distinct direct positive impact on learning orientation. And $H 2$ is supported.

(c) The relationship between administrative innovation and market orientation: this study supposed that market orientation has a positive impact on administrative innovation ( $\mathrm{H} 3 \mathrm{a}$ ) and we found that the fit of $\mathrm{M}_{2}$ mode has no distinct difference $\left(\Delta \chi^{2}=0.14, \Delta d . f .=1\right)$, which shows that market orientation has no distinct direct impact on administrative innovation. While from the route coefficients of the theory model in Table 7, we can also found that market orientation has no positive route coefficient to administrative innovation and there is no positive direct impact effect $\left(\gamma_{31}=0.07\right)$, which shows that the higher degree of market orientation does not mean the higher degree of administrative innovation. So, market orientation has no distinct direct positive impact on administrative innovation. And H3a is not supported.

(d) The relationship between technical innovation and market orientation: this study supposed that market orientation has a positive impact on technical innovation $(H 3 b)$ and we found that the fit of $M_{4}$ mode has no distinct difference $\left(\Delta \chi^{2}=2.25, \Delta d . f .=1\right)$, which shows that market orientation has no distinct direct 
impact on technical innovation. While from the route coefficients of the theory model in Table 7, we can also found that market orientation has no distinct positive route coefficient to technical innovation and there is no positive direct impact effect $\left(\gamma_{11}=0.34, p<0.001\right)$, which shows that the higher degree of market orientation does not mean the higher degree of technical innovation. So, market orientation has no distinct direct positive impact on technical innovation. And H3b is not supported.

(e) The relationship between administrative innovation and learning orientation: this study supposed that learning orientation has a positive impact on administrative innovation ( $\mathrm{H} 4 \mathrm{a}$ ) and we found that the fit of $\mathrm{M}_{5}$ mode has distinct difference $\left(\Delta \chi^{2}=17.88, \Delta\right.$ d.f. $\left.=1, p<0.001\right)$, which shows that learning orientation undoubtedly has a distinct impact on administrative innovation. While from the route coefficients of the theory model in Table 7, we can also found that learning orientation has positive route coefficient to administrative innovation and there is positive direct impact effect $\left(\gamma_{21}=0.79, p<0.05\right)$, which shows that the higher degree of learning orientation matches with the higher degree of producing administrative innovation. Therefore, learning orientation undoubtedly has a significant direct positive impact on administrative innovation. And $\mathrm{H} 4 \mathrm{a}$ is supported.

(f) The relationship between technical innovation and learning orientation: this study supposed that learning orientation has a positive impact on technical innovation $(H 4 b)$ and we found that the fit of $\mathrm{M}_{6}$ mode has a distinct difference $\left(\Delta \chi^{2}=4.00, \quad \Delta d . f .=1, \quad p<0.05\right)$, which shows that learning orientation undoubtedly has distinct impact on technical innovation. While from the route coefficients of the theory model in Table 7, we can also found that learning orientation has a positive route coefficient to technical innovation and there is a positive direct impact effect $\left(\gamma_{11}=0.45, p<0.001\right)$, which shows that the higher degree of learning orientation, the higher degree of producing technical innovation. Hence, learning orientation undoubtedly has a distinct direct positive impact on technical innovation. And $H 4 b$ is supported.

(g) The relationship between organizational performance and administrative innovation: this study supposed that administrative innovation has a positive impact on organizational performance $(H 5 a)$ and we found that the fit of $M_{7}$ mode has distinct difference $\left(\Delta \chi^{2}=7.63, \Delta d . f .=1, p<0.01\right)$, which shows that administrative innovation undoubtedly has a distinct impact on organizational performance. While from the route coefficients of the theory model in Table 7, we can also found that administrative innovation has a positive route coefficient to organizational performance and there is a positive direct impact effect $\left(\beta_{11}=0.59, p<0.01\right)$, which shows that the higher degree of administrative innovation, the higher degree of inducing organizational performance directly. Administrative innovation undoubtedly has a distinct direct positive impact on organizational performance. And $H 5 a$ is supported. 
(h) The relationship between organizational performance and technical innovation: this study supposed that technical innovation has a positive impact on organizational performance $(H 5 b)$ and we found that the fit of $M_{8}$ mode has no distinct difference $\left(\Delta \chi^{2}=3.19, \Delta d . f .=1\right)$, which shows that technical innovation has no distinct impact on organizational performance. While from the route coefficients of the theory model in Table 7, we can also found that the route coefficient of technical innovation to organizational performance does not achieve distinct level and there is no distinct direct impact effect $\left(\beta_{21}=0.23\right)$, which shows that the higher degree of technical innovation does not mean that the degree of inducing organizational performance directly is higher. Technical innovation has no distinct direct positive impact on organizational performance. And $H 5 b$ is not supported.

(i) The relationship between administrative innovation and technical innovation: this study supposed that technical innovation has a positive impact on administrative innovation (H4) and we found that the fit of $M_{9}$ mode has distinct difference $\left(\Delta \chi^{2}=9.16, \Delta d . f .=1, p<0.01\right)$, which shows that technical innovation undoubtedly has a distinct impact on administrative innovation. While from the route coefficients of the theory model in Table 7 , we can also found that technical innovation has a positive route coefficient to administrative innovation and there is a positive direct impact effect $\left(\beta_{31}=0.28, p<0.001\right)$, which shows that the higher degree of technical innovation, the higher degree of inducing administrative innovation directly. And technical innovation undoubtedly has a distinct direct positive impact on administrative innovation. So $H 4$ is supported.

\subsection{Analysis of results of the impact among variables}

There are three impacts among variables including direct impact, indirect impact and total impact with respect to the analysis on the influence among variables. Total impact equals to the sum of direct impact and indirect impact and direct impact has been shown above in the hypothesis validation.

Fig. 2 and Table 8 show that on the indirect impact and total impact, market orientation has distinct indirect positive impact on organizational performance through the routes of $\gamma_{11} \beta_{11} \beta_{21}$ and $\gamma_{11} \beta_{12} \beta_{3} \beta_{21}$ separately. Their values are 0.53 and 0.16 and the total impact is 0.69 . It is obvious that though market orientation has no distinct direct impact on organizational performance, it still has distinct impact on organizational performance through learning orientation, administrative innovation and technical innovation. Learning orientation has distinct indirect positive impact on organizational performance through the routes of $\beta_{11} \beta_{21}$ and $\beta_{12} \beta_{3} \beta_{21}$. Their values are 0.58 and 0.17 and the total impact is 0.75 . It is obvious that administrative innovation and technical innovation have distinct positive impact on organizational performance through learning orientation and technical 


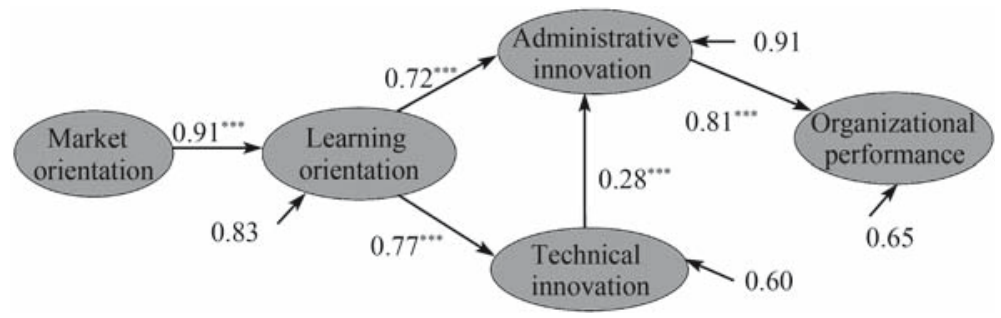

Fig. 2 The overall modificatory theory model

Table 17 Analysis of impacts on organizational performance by variables

\begin{tabular}{lccccc}
\hline Impact variables & Direct & \multicolumn{3}{c}{ Indirect impact (Via) } & Total impact \\
\cline { 3 - 5 } & impact & $\begin{array}{c}\text { Learning } \\
\text { orientation }\end{array}$ & $\begin{array}{c}\text { Administrative } \\
\text { innovation }\end{array}$ & $\begin{array}{c}\text { Technical } \\
\text { innovation }\end{array}$ & \\
\hline Market orientation & - & 0.69 & - & - & 0.69 \\
Learning orientation & - & - & 0.58 & 0.17 & 0.75 \\
Administrative innovation & 0.81 & - & - & - & 0.81 \\
Technical innovation & - & - & 0.19 & - & 0.19 \\
\hline
\end{tabular}

Note: The value in the table comes from the calculation of standard coefficient.

innovation has no direct impact on organizational performance but has indirect impact through administrative innovation of the route $\beta_{3} \beta_{21}$ and the value is 0.19 . These findings are not consistent with the results studied by foreign scholars who consider that technical innovation is the same as administrative innovation which both have distinct direct impact on organizational performance.

From the view of total impact, in our model, administrative innovation has the most profound impact on organizational performance and technical innovation has the least. In the managing practices, enterprises can realize that they need improve products and techniques and improve the quality of products or reduce the cost through technical innovation to enhance the competition of the product and the competitive advantage. But from the result above, we can see that the understanding above is not comprehensive. Enterprises need administrative innovation and the potential of technical innovation to build competitive advantage.

\section{Discussion and conclusions}

\subsection{Discussion}

This paper takes learning orientation and organizational innovation as mediator to link the market orientation and organizational performance, aiming at 
discussing the relationships among market orientation, learning orientation, organizational innovation and organizational performance. We constructed a theoretic model through literature study and review and selected enterprises in south of China as objects of this empirical study. The study indicates that market orientation can affect organizational performance through organizational innovation. The findings are as follows: (1) market orientation has no positive direct impact on organizational performance; (2) market orientation has a distinct direct impact on learning orientation, while it is not on organizational innovation; (3) learning orientation has a distinct direct impact on administrative and technical innovation; (4) market orientation has a distinct direct impact on organizational innovation through learning orientation; (5) administrative innovation has a positive direct impact on organizational performance while technical innovation does not impact organizational performance directly; (6) organizational innovation can be divided into administrative innovation and technical innovation, and technical innovation has a distinct positive impact on administrative innovation; (7) learning orientation can impact organizational performance indirectly by organizational innovation; and (8) market orientation can impact learning orientation, then impact organizational innovation, and finally impact organizational performance.

\subsection{Managerial implications}

The results of this paper confirm the argumentations on that market orientation has a positive impact on organizational performance (Kohli and Jaworski, 1990; Narver and Slater, 1990; Jaworski and Kohli, 1993; Han et al., 1998; Baker and Sinkula, 1999; Lin, 2001; Tse et al., 2003), and approve that learning orientation and organizational innovation are mediator in the relationship between market orientation and organizational performance.

The results of this study further affirm that market orientation is the inducement to learning orientation and the same as learning orientation to organizational innovation. Therefore, organizations have to pay attention to the culture of market orientation, and stimulate organization learning, and then create innovation according to market information obtained, which is a kind of innovational impetus from outside to inside. On the other hand, organizations also have to pay attention to the culture of learning orientation, and urge to create innovation by the stimulation of market information outside and the ability of learning, which is a kind of innovational impetus from inside to outside (Lin, 2001). Learning orientation is a key factor to advance competence by the corporate culture of market orientation, because learning orientation is one of the essential ways to improve the innovation capability. The result is as important as the view indicated by Slater and Narver (1995) that enterprises must work in an appropriate 
environment of learning orientation when implementing the culture of market orientation. Lin (2001) also proved that learning orientation plays an important mediatory role in the relationship of market orientation and organizational innovation. However, different from his result, we find that market orientation has no direct distinct impact on organizational innovation but has an indirect distinct impact through learning orientation.

From the whole model and its test we know that learning orientation has a positive impact on organizational innovation, and learning orientation has a distinct direct impact on organizational performance through administrative innovation but indistinctive through technical innovation. Technical innovation has distinct indirect impact on organizational performance through administrative innovation. The result of this study reveals that organizational innovation is a mediator in the relationship of market orientation and performance. Enhancing innovational ability is one of the feasible ways if an organization wants to improve organizational performance through the culture of market orientation. And the result of this study is in accordance with the conclusions of Han et al. (1998), and Lin (2001). Enterprises need not only to create corporate culture of market orientation but also strengthen organizational innovation to promote organizational performance under the circumstances of furious competition and the shorter product life circle. The evolvement of modern industry is from not only technical innovation but also the impact of logistics, capital flow, human flow, information flow and so on. Some enterprises have come into new area for further development while some others follow them bitterly. Do those successful enterprises have a good fortune or can they really forecast the opportunities? No. What the genius depends on is the spirit of innovation and enterprises (Wu, 2002), and it is innovation that makes enterprises obtain excellent capabilities on environment management and develop enterprises' competitive advantage, thus innovation becomes the source of excess profit under the uncertain environment. Han et al. (1998) took banking and Lin (2001) took high-tech enterprises in Taiwan of China as study object while our research took enterprises in southern china as the study object. All these studies approve the relationship of market orientation, learning orientation, organizational innovation and organizational performance. Obviously the relationship is not limited in high-tech industry or a certain special industry or a certain region, and this is the scientific significance of the research.

However, Lin (2001) considered that both technical innovation and administrative innovation have distinct positive direct impact on organizational performance in high-tech enterprises in Taiwan of China, while we find that technical innovation has no distinct direct impact on organizational performance but only has distinct positive impact through administrative innovation. The reason may be the immature of business management in mainland or the 
restriction against the role of technical innovation by the administrative mechanism, and this may be the reason why enterprises in China attach more attention to administrative innovation in recent years. This also tells us that enterprises in our country need to strengthen administrative innovation when emphasizing technical innovation. In the end, administrative innovation plays an important role in the chain of market orientation - organizational innovationorganizational performance and it is the bottleneck on the enhancement of organizational performance. In general, market orientation can not spur the enhancement of organizational performance directly unless through learning orientation and organizational innovation.

We consider that market orientation has five factors, including customer orientation, competitor orientation, inter-functional coordination, long-term horizon and profit emphasis. Learning orientation has three aspects, including commitment to learning, shared vision and open-mindedness. Organizational innovation has two factors, including administrative innovation and technical innovation. Organizational performance can be divided into short-term performance and long-term performance. Questionnaires of all these variables are also suitable to the fact of enterprises in China. Different factors of market orientation have different impact on learning orientation, so are learning orientation and organizational innovation, organizational innovation and organizational performance. For example, inter-functional coordination of market orientation has greater impact on the commitment to learning and shared vision of learning orientation. The factor of long-term horizon of market orientation has a greater impact on the open-mindedness of learning orientation. The factor of customer orientation has no distinct impact on every factor of learning orientation, organizational innovation and organizational performance. Thus, customers affect little on learning orientation and innovation, that is to say, learning orientation and innovation do not depend on customers' need, although many enterprises in China consider market orientation is equal to customer orientation.

\subsection{Limitations}

Although this paper obtained many important conclusions to the theory and practice of business management, there are also some limitations. (1) We did not consider the impact of different industries in the process of bringing organizational innovation into the relationship of market orientation and organizational performance. Posterior researches can study some special characteristics of different industries, and find the impact to this relationship by industry characteristic. (2) Because the sample of this paper was mainly from enterprises in Pearl River Delta region of China and the results have not been confirmed in other regions, posterior researches can do some comparative study in the future. 
Acknowledgements This research is sponsored by the National Natural Science Fund of China (NSFC) under Grant 70401012 and 70572095, China Postdoctoral Science Foundation under Grant 20060390209 and the Natural Science Fund of Guangdong Province under Grant 05006596 .

\section{References}

Argyris C, Schon D (1978). Learning orientation: A theory of action perspective. Reading. MA: Addison-Wesley

Argyris C (1977. Double loop learning in organizations. Harvard Business Review, (Sep./Oct.): 115-125

Bagozzi R P, Yi Y (1988). On the evaluation of structural equation models. Academy of Marketing Science, (16): 76-94

Baker W E, Sinkula J M (1999). The synergistic effect of market orientation and learning orientation on organizational performance. Journal of the Academy of Marketing Science, 27(4): 411-427

Chen Guoquan, Ma Meng (2000). Learning orientation: Current status and its futere. Journal of Management Science, (1): 66-74 (in Chinese)

Damanpour F, Evan W M (1984). Organizational innovation and performance: The problem of 'Organizational Lag'. Administrative Science Quarterly, (Sep.): 392-409

Damanpour F. (1991). Organizational innovation: A meta-analysis of effects of determinants and moderators. Academy of Management Journal, 34(3): 555-590

Damanpour F, Szabat K A, Evan W M (1989). The relationship between types of innovation and organizational performance. Journal of Management Studies, (Nov.): 587-601

Drucker P F (1954). The Practice of Management. New York: Harper and Row Publishers

Foster G. (1986). Financial Statement Analysis. Englewood Cliffs, NJ: Pentice-Hall

Glynn M A (1996). Innovative genius: A framework for relating individual and organizational intelligences to innovation. Academy of Management Review, 21(4): 1081-1111

Hair J J, Anderson R, Tatham R, Black W (1998). Multivariate Data Analysis, 5th ed., Upper Saddle River, NJ: Prentice-Hall

Han J K, Kim N, Srivastava R K (1998). Market orientation and organizational performance: Is innovation a missing link? Journal of Marketing, 62(4): 30-45

Hult G T M, Ferrell O C (1997). Global learning orientation capacity in purchasing: Construct and measurement. Journal of Business Research, (40): 97-111

Jaworski B J, Kohli A K (1993). Market orientation: Antecedents and consequences. Journal of Marketing, (57): 53-70

Kohli, Jaworski (1990). Market orientation: The construct, research propositions \& managerial implication. Journal of Marketing, 54(2): 1-18

Kumar K, Subramanian R, Yauger C (1998). Examining the market orientation-performance relationship: A context-specific study. Journal of Management, 24(2): 201-233

Langerak F (2003). An appraisal of research on the predictive power of market orientation. European Management Journal, 21(4): 447-464

Lin Yiping (2001). A Study of the Relationships among Market Orientation, Learning Orientation, Organizational Innovation and organizational performance: A case of the communication industry in science garden. Unpublished paper for doctor degree of business administration, National Sun Yat-Sen University (in Chinese)

Mabey C, Salaman G (1995). Strategic Human Resource Management. Oxford: Blackwell 
March J G, Simon H (1958). Organizations. Oxford: Blackwell Business

McKee D (1992). An organizational learning approach to product innovation. Journal of Product Innovation Management, (9): 234

Narver J C, Slater S F (1990). The effect of a market orientation on business profitability. Journal of Marketing, 54(4): 20-35

Porter M E (1980). Competitive Strategy: Techniques for Analysizing Industrial \& Competitors. Oxford: Blackwell Ingram

Powell W W, Koput K W, Smith-Doerr L (1996). Interorganizational collaboration and locus of innovation: Networks of learning in biotechnology. Administrative Science Quarterly, (41): 116-145

Quinn J B (1986). Innovation and Corporate Strategy: Managed Chaos, in Technology in the Modern Corporation: A Strategic Perspective. Horwich M, ed. New York: Pergamon Press

Schumpeter J A (1934). The Theory of Economic Development. Boston: Harvard

Senge P M (1990). The Fifth Discipline. New York: Doubleday

Shapiro B P (1988). What the hell is 'market oriented'? Harvard Business Review, (Nov./Dec.): $119-125$

Sinkula J M, Baker W E, Noordewier T (1997). A framework for market-based organizational learning: Linking values, knowledge, and behavior. Journal of the Academy of Marketing Science, 25(4): 305-318

Slater S F, Narver J C (1995). Market orientation and the learning organization. Journal of Marketing, (59): 63-74

Slater S F (1997). Developing a customer value-based theory of the firm. Journal of the Academy of Marketing Science, (25): 162-167

Stata R (1989). Learning orientation-the key to management innovation. Sloan Management Review, (Spring): 63-74

Steers R M (1975). Problems in the measurement of organizational effectiveness. Administrative Science Quarterly, 20(4): 546-558

Subramaian A, Nilakanta S (1996). Organization innovativess: Exploring the relationship between organization determinants of innovation, types of innovations, and measures of organizational performance. Omega, International Journal of Management Science, 24(6): 631-647

Trist E L (1981). The Evolution of Socio-Techniocal Systems as a Conceptual Framwork and as an Action Research Program. In: Van de Ven A H, Joyce W F, eds. Perspectives on Organization Design and Behavior. New York: John Wiley \& Sons

Tse Alan C B, Sin Leo Y M, Yau H M Oliver, Lee S Y Jenny, Chow R (2003). Market orientation and business performance in a Chinese business environment. Journal of Business Research, 56(3): 227-239

Wolfe R A (1994). Organizational innovation: review, critique and suggested research directions. Journal of Management Studies, 31(3): 405-430

Wu Sihua (2002). Nine Points for Strategy. The Press of Fudan University (in Chinese)

Zahra S A, de Belardino S, Boxx W R (1988). Organizational innovation: Its correlates and its implications for financial performance. International Journal of Management, (5): 133-142

Zaltman G, Duncan R, Holbek J (1973). Innovations and Organizations. New York: Wiley 